Boise State University

ScholarWorks

$12-2020$

\title{
Harvester Ants Reduce Seed Survivorship in Slickspot Peppergrass, a Rare Mustard Endemic to Idaho
}

Jennifer A. Brown

Boise State University

Ian C. Robertson

Boise State University 


\title{
Harvester ants reduce seed survivorship in slickspot peppergrass, a rare mustard endemic to Idaho
}

\author{
Jennifer A. Brown ${ }^{1}$ and Ian C. Robertson ${ }^{1, *}$ \\ ${ }^{1}$ Department of Biological Sciences, Boise State University, 1910 University Dr., Boise, ID 83725
}

\begin{abstract}
Seed predation can significantly reduce the reproductive success of individual plants and their populations. The consequences of seed predation often are most pronounced for rare plant species, in which loss of seeds can have a disproportionate effect on populations. The present study examined the effects of seed predation by Owyhee harvester ants (Pogonomyrmex salinus) on seed survivorship in slickspot peppergrass (Lepidium papilliferum), a rare mustard endemic to sagebrush-steppe habitat in southwestern Idaho. Within sagebrush-steppe, L. papilliferum is restricted to microsites known as "slick spots"- shallow depressions of soil characterized by distinct clay layers and surface water retention that is higher than that of surrounding areas. Harvester ants frequently nest in L. papilliferum habitat and readily consume the plant's seeds. We conducted a controlled field experiment at a population of L. papilliferum in 2012 to quantify seed loss to individual plants as a result of seed predation by harvester ants. Across 20 slick spots, plants exposed to harvester ants experienced a median reduction in seed survivorship of $89.2 \%$ (interquartile range, $69.3 \%$ to $93.9 \%$ ) relative to plants in the same slick spot that were matched for size and shielded from ants. The proportion of seeds that plants lost to seed predation was more variable and significantly lower in slick spots with $>150$ plants than in those with fewer plants, suggesting that a threshold to the number of seeds that can be collected and consumed by ants may occur within the natural range of plant densities found in slick spots. Our results suggest that slick spots supporting large numbers of L. papilliferum in a given year may be buffered from the effects of predation, whereas those with relatively few plants are particularly vulnerable to high levels of seed loss to harvester ants.
\end{abstract}

RESUMEN.-La depredación de semillas puede reducir significativamente el éxito reproductivo de las plantas individuales y sus poblaciones. Las consecuencias de la depredación suelen ser más evidentes en las especies de plantas exóticas, potencialmente teniendo un efecto desproporcionado en las poblaciones. En el presente estudio, investigamos los efectos de la depredación de las hormigas Pogonomyrmex salinus en la supervivencia de las semillas de las hierbas Lepidium papilliferum, una planta de mostaza endémica al hábitat de estepas de artemisas del sudoeste de Idaho. Dentro de las estepas de artemisas, la L. papilliferum se restringe a micrositios conocidos como "zonas resbaladizas", depresiones del suelo caracterizadas por distintas capas de arcilla y retención de agua superficial, mayor a la de las áreas circundantes. Las hormigas Pogonomyrmex salinus con frecuencia anidan en el hábitat de las L. papilliferum y rápidamente consumen las semillas de la planta. En 2012, realizamos un trabajo de campo controlado en una población de L. papilliferum, para cuantificar la pérdida de semillas en plantas individuales como resultado de la depredación por parte de las hormigas Pogonomyrmex salinus. En 20 zonas resbaladizas, las plantas expuestas a las hormigas experimentaron una reducción promedio de la supervivencia de sus semillas del 89.2\% (rango intercuartil, 69.3\%-93.9\%) relativo a otras plantas de igual tamaño en la misma zona, que fueron protegidas de las hormigas. La proporción de semillas perdidas como consecuencia de la depredación fue más variable y significativamente menor en las zonas resbaladizas con > 150 plantas, que en aquellas zonas con menos plantas, sugiriendo que podría haber un umbral en la cantidad de semillas que las hormigas pueden recolectar y consumir, dentro de la distribución natural de las plantas encontradas en estas zonas resbaladizas. Nuestros resultados indican que las zonas resbaladizas con grandes cantidades anuales de L. papilliferum pueden estar protegidas de los efectos de la depredación, mientras que aquellas con relativamente pocas plantas son particularmente vulnerables a altos niveles de pérdida de semillas a causa de la depredación por parte de las hormigas Pogonomyrmex salinus.

Harvester ants in the genus Pogonomyrmex are important seed consumers in the arid and semiarid grasslands of North America (MacMahon et al. 2000). Their foraging activities have the capacity to remove large numbers of seeds from the environment, which can alter the composition of plant communities and the dynamics of populations (Reichman 1979, Inouye et al. 1980, MacMahon et al. 2000). The detrimental effects of seed predation may be

\footnotetext{
*Corresponding author: iroberts@boisestate.edu
} 
particularly consequential for rare plants, in which any loss of seeds could limit or prevent population recovery (Ancheta and Heard 2011). Because seed predation can be a major contributing factor to low recruitment of individuals in rare plant populations (Crawley 2000, Albert et al. 2005), measuring the effect of seed predation on seed survivorship under natural conditions is an important first step in the assessment of how seed predation may impact vital rates of a rare species. Here we measure the effects of seed predation by Owyhee harvester ants, Pogonomyrmex salinus (Olsen) (Hymenoptera: Formicidae), on seed survivorship in slickspot peppergrass, Lepidium papilliferum (L. Hend.) A. Nelson \& J.F. Macbr. (Brassicaceae), a rare mustard endemic of sagebrushsteppe habitat in southwestern Idaho.

Within sagebrush-steppe, L. papilliferum is restricted to microsites known as "slick spots" (Moseley 1994) — shallow depressions of natric soils characterized by distinct clay layers and surface water retention that is higher than that of surrounding areas (Fisher et al. 1996). The unique habitat requirements of L. papilliferum, along with the plant's limited range and declining numbers (Mancuso and Moseley 1998, Bond 2017), has raised concerns about the species' long-term viability. Range-wide declines in L. papilliferum have been largely attributed to the loss of suitable habitat as a result of urbanization, agriculture, livestock grazing, the spread of invasive species, and increased wildfire frequency (Moseley 1994). More recently, seed predation by Owyhee harvester ants has been identified as a potentially important source of seed loss that may contribute to population declines of the species (United States Fish and Wildlife Service 2016).

Owyhee harvester ants, like many other Pogonomyrmex species, collect and consume seeds from a variety of small-seeded plant species (MacMahon et al. 2000). Among the seeds available to Owyhee harvester ants, those of slickspot peppergrass are often overrepresented in the ant's diet (Schmasow and Robertson 2016). The vulnerability of L. papilliferum seeds to predation by $P$. salinus may be enhanced by the combined effects of the ant's foraging behavior and the plant's specialized habitat requirements. Like many Pogonomyrmex species, $P$. salinus forages collectively along trunk trails that lead to food patches (Janzen 1971, Hölldobler and Wilson 1990). Mobilization of foragers to food patches decreases individual search times and increases the cumulative number of seeds collected from patches (MacMahon et al. 2000). Because L. papilliferum is restricted to growing in slick spots, its seeds become concentrated in dense patches that harvester ants can readily exploit. While these concentrated patches of seeds may facilitate seed predation, the proportion of seeds lost by individual plants should be subject to a dilution effect (Wenninger et al. 2016) once seed availability in a patch exceeds the consumption threshold of the predators (Janzen 1971, Kelly 1994).

In a preliminary analysis of seed loss to harvester ants, White and Robertson (2009) reported that ants removed, on average, at least $40 \%$ of mature fruit directly from L. papilliferum plants, and scavenged seeds from the ground beneath the plants. However, the study did not assess the combined effects of pre- and postdispersal seed loss to individual plants, nor did it consider the possibility of a dilution effect (via predator satiation) in response to total seed availability within slick spots. Subsequent research found that predispersal seed loss (i.e., fruit removal), while sometimes intense, occurs sporadically and often represents only a portion of total seed loss (Robertson unpublished data). More often, ants collect seeds from the soil surface beneath plants after the seeds dehisce from their fruits (Jeffries 2016, Schmasow and Robertson 2016).

In the present study, we compared seed survivorship of L. papilliferum plants that were exposed to harvester ants relative to sizematched plants in the same slick spot that were protected from ants. We also tested whether the proportion of seeds lost by plants exposed to harvester ants, which we established via a comparison of seed numbers with their size-matched and protected counterparts, was inversely related to the total number of plants present in a slick spot. We predicted that the foraging activities of harvester ants would significantly reduce seed survivorship at levels equal to or exceeding those reported by White and Robertson (2009), and that the proportion of seeds harvested from individual plants would decrease as the number of L. papilliferum plants within a slick spot increased, at least once the number of seeds available in the slick spot reached the colony's threshold for consumption (i.e., satiation threshold). 


\section{METHODS}

\section{Study Area}

We conducted the study from June to October 2012 at a population of L. papilliferum located near Melba, Idaho. The site was chosen because it supports a relatively large population of L. papilliferum and has an abundance of harvester ant colonies ( $\sim 25.5$ colonies/ha). Overstory vegetation consisted of sparsely distributed patches of Artemisia tridentata (big sagebrush) and Ericameria nauseosa (rubber rabbitbrush), while the understory was dominated by Poa secunda (Sandberg bluegrass), Bromus tectorum (cheatgrass), and Sisymbrium altissimum (tall tumble mustard).

\section{Study Species}

OWYHEE HaRVESTER ANTS.-Pogonomyrmex salinus, the northernmost member of the genus, occurs from southwestern Canada through Idaho, Washington, Oregon, northeastern California, Nevada, and western portions of Utah, Montana, and Wyoming (Cole 1968, Taber 1998). A mature colony typically consists of 5000 to 10,000 workers (MacKay 1981, Johnson 2000), and, like other Pogonomyrmex species, may survive 15-20 years, sometimes longer (Porter and Jorgensen 1988, MacMahon et al. 2000), as long as the founding queen survives and continues to lay eggs (Gordon 1991). Colonies are active aboveground from spring to autumn whenever surface temperatures are sufficiently warm (Crist and MacMahon 1991, Taber 1998). Daily foraging activity usually occurs in the morning and late afternoon, with periods of inactivity during the hottest portions of the day (Hobbs 1985, Crist and MacMahon 1991). Pogonomyrmex ants are singleload, central place foragers (Stephens et al. 2007). They forage up to $20 \mathrm{~m}$ from their nest, with a majority of foraging occurring within $12 \mathrm{~m}$ of the nest (MacMahon et al. 2000, White and Robertson 2009). When P. salinus nests are in close proximity to one another (i.e., $<20 \mathrm{~m}$ apart), neighboring colonies share nonoverlapping boundaries in the areas between their nests (Howell and Robertson 2015).

SLICKSPOT PEPPERGRASS.-Lepidium papilliferum is a small mustard endemic to sagebrush-steppe habitat in southwestern Idaho. Presently, there are fewer than 100 known locations where the plant occurs, and many of these locations are heavily disturbed and sparsely populated (Miller and Kinter 2018). Owing to L. papilliferum's limited distribution, specific habitat requirements, and declining numbers, the plant was granted federal protection as a threatened species in 2016 (United States Fish and Wildlife Service 2016). It exhibits 2 life history patterns-annuals that germinate, reproduce, and die within a single season, and biennials that exist as vegetative rosettes in their first year and reproduce and die in their second year (Meyer et al. 2005). An averagesized biennial $(\sim 12-15 \mathrm{~cm}$ in overhead diameter) produces 1200-1700 seeds, whereas annuals usually produce fewer than 250 seeds (Schmasow 2015). The plant's flowers, which typically bloom from mid-May to late June, rely on outcrossed pollination mediated by insects (Robertson and Klemash 2003). Each mature fruit, or silicle (Holmgren et al. 2005), bears 2 seeds that drop to the ground when the fruit dehisces late in summer. These seeds become part of a persistent seed bank that in some years may represent the majority of the population (Mancuso and Moseley 1998). Seeds can remain viable in the seed bank for up to 12 years (Meyer et al. 2005), perhaps longer.

\section{Seed Predation Experiment}

We selected 20 slick spots that were occupied by flowering L. papilliferum and located within $8 \mathrm{~m}$ of an active $P$. salinus colony. This distance is well within the $12-\mathrm{m}$ foraging range typical of harvester ants (Jorgensen and Porter 1982, MacMahon et al. 2000, personal observations). Each ant colony foraged within only one slick spot occupied by L. papilliferum. We recorded the total number of flowering $L$. papilliferum plants in each slick spot. Although we did not enumerate these plants by size, most of the flowering plants in slick spots were either midsized biennials $(12-15 \mathrm{~cm}$ in diameter) or vegetative (i.e., nonflowering) biennial rosettes. Very few flowering annuals were present at the site in 2012.

Within each slick spot, we selected 2 flowering L. papilliferum plants matched for size (overhead surface area), flowering phenology, and distance from the ant colony. One plant from each pair was randomly assigned to the treatment (ants excluded) and the other to the control (access by ants). To prevent access by ants, we fixed a 15-cm-high, 30-cm-diameter plastic barrier $2 \mathrm{~cm}$ deep in the soil around the base of each treatment plant. Metal stakes 
were used to secure each barrier firmly to the ground. We placed a similar barrier around each control plant; however, supports were used to elevate these barriers $3-5 \mathrm{~cm}$ above the ground to permit access by harvester ants. Metal stakes were used to hold the barriers in place. We affixed wire mesh over the tops of all barriers to exclude vertebrates while allowing access to plants by insect pollinators.

To account for the possibility that the elevated barriers around control plants may have allowed L. papilliferum seeds to disperse beyond the perimeter of their barriers, thereby confounding any effects of seed predation with seed drift, at 10 of the 20 slick spots we selected a third L. papilliferum plant that was matched with the other 2 for size, flowering phenology, and distance from ant colony. We first placed an elevated 30-cm-diameter barrier around these plants, as described previously for control plants. We then centered a larger plastic barrier, $60 \mathrm{~cm}$ in diameter and $15 \mathrm{~cm}$ in height, around the elevated barrier. This larger barrier was fixed $2 \mathrm{~cm}$ deep in the soil and secured in place with metal stakes. Wire mesh was secured over the top of the elevated barrier. Any seeds that drifted beyond the perimeter of the inner barrier would be confined to the soil between the inner and outer barriers.

In mid-October, once fruits had dehisced and dropped their seeds to the ground and all signs of foraging within slick spots had ceased, we collected the upper $1 \mathrm{~cm}$ of soil located within the perimeter of the $30-\mathrm{cm}$ barrier surrounding each plant. The soil samples were placed in paper bags, one bag per plant, and returned to the laboratory. We sifted individual samples through a series of increasingly finer sieves $(1.4 \mathrm{~mm}, 850 \mathrm{~mm}, 710 \mathrm{~mm}$, $500 \mathrm{~mm}$, and 250-mm-diameter mesh; Hogentogler \& Co., Inc., Columbia, MD) and counted the L. papilliferum seeds trapped by each layer of mesh. We counted only "sound" seeds (Crist and MacMahon 1992). A seed was considered sound (and presumably viable) if it was intact and withstood light pressure from forceps without breaking. Seeds that were not sound typically consisted of seed coats and little or no endosperm.

\section{Foraging Observations}

To confirm that harvester ants were active and foraging on L. papilliferum seeds in all
20 slick spots included in our study, we conducted observations at each of those slick spots several times per week from June through September. During each set of observations, we noted (1) the presence of harvester ants in the slickspot and whether these ants were collecting and transporting L. papilliferum fruits and/or seeds to their nest, (2) physical signs that ants had clipped seed-bearing fruits directly from L. papilliferum plants (see Fig. la in White and Robertson 2009), and (3) the presence of L. papilliferum fruit husks in the middens of nest mounds. In mid-July, at 16 of the 20 ant colonies, we aspirated 15-30 harvester ants as they returned to their respective nests. Ant activity at the remaining 4 colonies was deemed too low at the time to permit sufficient sampling. The ants we aspirated were placed in glass vials, one vial per colony, along with any food items they were carrying (note: when aspirated, harvester ants steadfastly hold onto food in their mandibles). In the laboratory, we viewed the contents of each vial under $10 \times$ magnification and recorded the number and identity of all seeds present.

\section{Statistical Analyses}

Using R version 3.5.3 (R Development Core Team 2013), we conducted a paired $t$ test to analyze the "access by ants" and "ants excluded" data $(n=20)$ from the seed predation experiment. Prior to analysis, we log-transformed seed counts to achieve a normal distribution of the residuals and homogeneity of variance. We then used the packages 'car' and 'lme4' in $\mathrm{R}$ to conduct a likelihood ratio test on the data that included the "seed drift" data from the seed predation experiment $(n=10)$. These data were fit into a generalized linear mixed model with "number of seeds on soil" as a function of treatment (i.e., access by ants, ants excluded, or seed drift). We included overhead flowering area as a fixed effect. Slick spot was added as a random effect to account for the influence that individual slick spots may have had on seed production by treatment and control plants. A planned comparison of the least-squares means of the 3 treatment levels was conducted using a Tukey's HSD test in R package 'lsmeans.'

To confirm that there were no significant treatment-related differences in the overhead flowering area of the plants in our experiment, we used a generalized linear mixed model to 


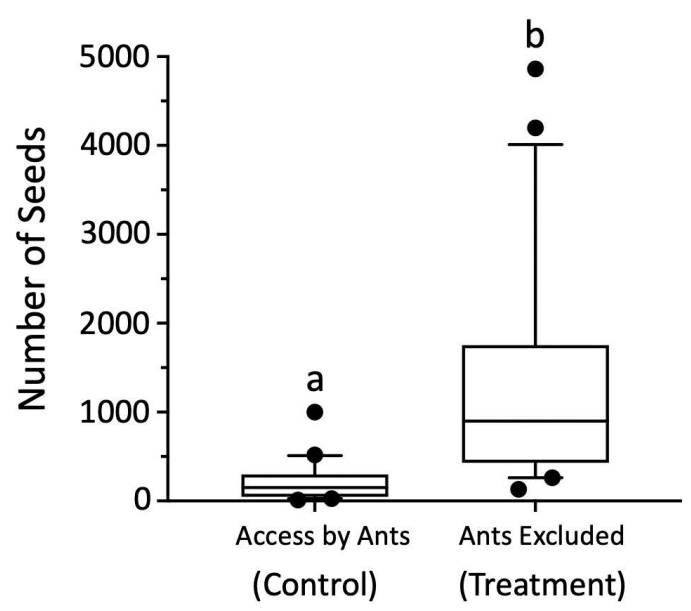

Fig. 1. Boxplot chart showing the number of Lepidium papilliferum seeds (untransformed values) remaining as a function of barrier treatment $(n=20)$. The 75 th and 25 th percentiles are indicated by the upper and lower limits of each box, respectively. The upper and lower ends of the whiskers represent the 90th and 10th percentile, respectively. The thick horizontal line within the box represents the median. Different letters above the bars indicate significant differences between the groups based on a means comparison of log-transformed values.

conduct a likelihood ratio test that compared overhead flowering area as a function of treatment. Slick spot was included as a random effect. The values for overhead flowering area were not distributed normally in any of the treatments or controls. Log-transformation of flowering area values created a normal distribution in all but the controls (i.e., access by ants), whereas squaring worsened the distribution. Therefore, we used log-transformed values. The overhead flowering area met the assumption of homoscedasticity prior to and after transformation.

We used a Wilcoxon rank-sum test in $\mathrm{R}$ package 'coin' to test whether there was a point at which an increased number of flowering L. papilliferum in a slick spot was associated with a significant decrease in proportion of seeds lost by individual plants, in which proportion of seeds lost $=(1-$ number of seeds from plant exposed to ants/number of seeds from plant shielded from ants]). We began by comparing values from slick spots with 1-50 L. papilliferum plants (low density) to those with $>50$ plants (high density). We then increased the range of values for low density in increments of 25 and made a corresponding adjustment to the range of values for high density (e.g., 1-75 and $>75$, followed by $1-100$ and $>100$, and so on). We repeated the test until a significant difference was found or we ran out of comparisons.

\section{RESUlTs}

\section{Seed Predation Experiment}

There was no statistically significant difference in the overhead flowering area of plants selected for the treatment, control, and seed drift groups $\left(\chi^{2}=0.602, \mathrm{df}=2, P=0.74\right)$. Significantly more seeds were present on the soil surface beneath plants from which ants were excluded than beneath plants that were exposed to ants (Fig. 1; paired $t$ test on transformed values: $\left.\mathrm{t}_{19}=-7.98, P<0.0001\right)$. In the comparison of the 20 matched pairs of plants, the median reduction in seeds when ants had access to plants was $89.2 \%$ (interquartile range, $63.9 \%$ to $93.9 \%$ ). This range included 2 instances in which control plants showed no reduction in seeds compared to their paired treatments, even though ants were observed foraging beneath L. papilliferum in those slick spots. When these 2 cases were removed from the analysis, the median reduction of seeds when ants had access to plants increased to $89.8 \%$ (interquartile range, $77.8 \%$ to $94.2 \%$ ).

The use of barriers to exclude harvester ants from access to L. papilliferum had a statistically significant effect on the number of seeds remaining on the soil surface when we compared values of the smaller subset of cases $(n=10)$ in which all 3 barrier types were present in a slick spot: access by ants, ants excluded, and seed drift (Fig. $2 ; \chi^{2}=17.18$, $\mathrm{df}=2, P=0.0002)$. Specifically, significantly more seeds were present on the soil directly beneath plants in the seed drift treatment (i.e., plants with a raised inner barrier and sealed outer barrier) than beneath plants that were exposed to ants (means comparison: $P=$ 0.0033). By contrast, there was no significant difference between the number of $L$. papilliferum seeds beneath plants in the seed drift treatment and the number in the ants-excluded treatment (means comparison: $P=0.81$ ). These results indicate that seed drift does not explain the low number of seeds found beneath $L$. papilliferum plants that were exposed to ants.

Control plants (i.e., caged plants that were accessible to ants) in slick spots with $\leq 150$ 


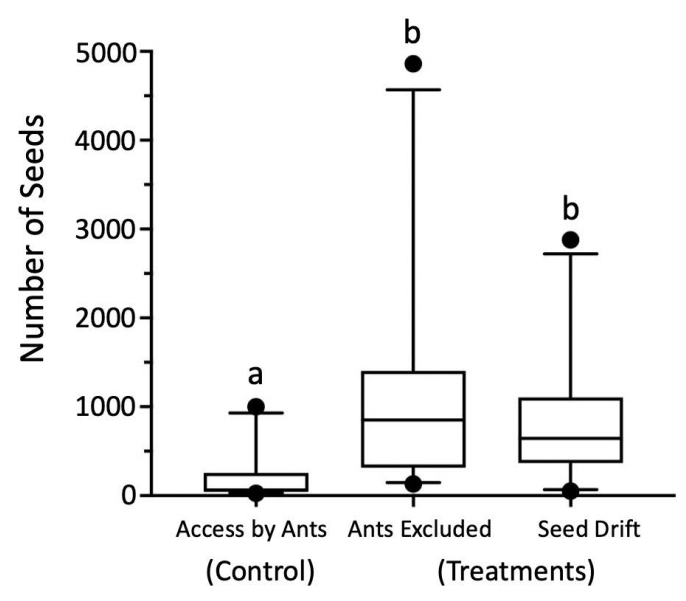

Fig. 2. Boxplot chart showing the number of Lepidium papilliferum seeds (untransformed values) remaining as a function of barrier treatment when only slick spots with the seed drift group are included $(n=10)$. The 75 th and 25th percentiles are indicated by the upper and lower limits of each box, respectively. The upper and lower ends of the whiskers represent the 90th and 10th percentile, respectively. The thick horizontal line within the box represents the median. Different letters above the bars indicate significant differences based on a means comparison of log-transformed values.

flowering L. papilliferum ("low density," $n=$ 14, range 28 to 137 flowering plants) lost a significantly higher proportion of their seeds than those in slick spots with $>150$ flowering L. papilliferum ("high density," $n=6$, range 181 to 647 flowering plants) $(0.87 \pm 0.03$ versus $0.51 \pm 0.17$, respectively; Fig. 3; Wilcoxon rank-sum test, $z=-2.23, P=0.024)$. No other pairings of pooled data for low- and high-density slick spots showed a statistically significant difference in the proportion of seeds lost by control plants.

\section{Foraging Observations}

We observed harvester ants foraging in all 20 slick spots, and L. papilliferum fruit husks were present in the middens of all 20 harvester ant colonies associated with a slick spot. In 16 of those slick spots, we observed ants climbing on L. papilliferum, and in 11 we found individual plants with signs of fruit that had been clipped from the plant. We found no signs of clipped fruits on plants situated within barriers sealed to the ground, nor did we find any harvester ants within the cages, which suggests that these barriers were effective at preventing seed predation by these

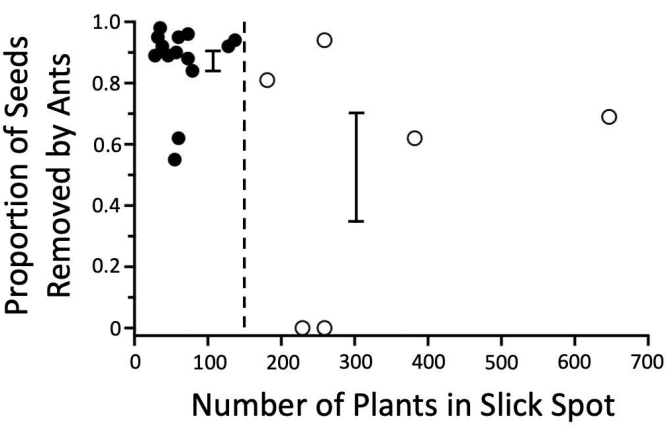

Fig. 3. The proportion of seeds removed from individual Lepidium papilliferum plants as a function of the number of flowering plants within slick spots. The dotted line indicates the inflection point where the proportion of seeds removed was significantly different between slick spots containing $>150$ plants and $\leq 150$ plants based on a Wilcoxon rank-sum test $(P=0.024)$. Filled and open circles represent low- and high-density slick spots, respectively. The solid vertical bars show the standard error $( \pm \mathrm{SE})$ of the mean proportion of seeds removed by ants for both the high- and low-density slick spots. The mean removal for low-density slick spots was $0.87 \pm 0.03$ compared to $0.51 \pm 0.17$ for high-density slick spots.

ants. Lepidium papilliferum fruits and seeds made up $74 \%$ percent of the 127 food items we collected from 370 ants aspirated near nest entrances $(n=16$ colonies, $\bar{x}=70 \%$ L. papilliferum seeds or fruit per colony [range $0 \%$ to $100 \%]$ ).

\section{Discussion}

Owyhee harvester ant colonies are a prominent feature of many L. papilliferum populations throughout the species' range. In a recent survey, harvester ant colonies were found at 28 of $39(72 \%)$ sites occupied by L. papilliferum (Miller and Kinter 2018). While the number and density of ant colonies on the landscape varies among populations (Robertson and Robertson 2020), in many locations, including our study site, nearly all slick spots occupied by L. papilliferum are situated within $10 \mathrm{~m}$ of an ant colony (Robertson unpublished data). We have shown that in such circumstances, harvester ants are capable of removing a large proportion of the seeds produced by $L$. papilliferum, at least when the number of plants in slick spots is $\leq 150$. Given the longevity of harvester ant colonies (14-30 years-Porter and Jorgenson 1988), those colonies located near slick spots with $L$. papilliferum represent a persistent source of annual 
seed mortality and a drain on recruitment to the soil seed bank.

Plants exposed to harvester ants experienced a median loss of $89.2 \%$ of their seeds relative to size-matched plants that were shielded from ants. We attribute these losses to seed predation by ants and not to the effect of seeds drifting beyond the perimeters of the raised barriers that surrounded control plants (Fig. 2). This conclusion is supported by our observations of harvester ants foraging within slick spots and returning L. papilliferum seeds to their nests, and by the presence of L. papilliferum fruit husks in the middens of all nests associated with the study. In a previous study, White and Robertson (2009) reported average predispersal seed losses in excess of $40 \%$ to individual L. papilliferum plants, but they were unable to provide more precise assessments because as fruits matured it became increasingly difficult to distinguish between seeds depredated by ants and those that had dropped following dehiscence of fruits. We overcame this limitation in the present study by measuring the combined effects of pre- and postdispersal seed losses.

The proportion of seeds lost by control plants in high-density slick spots ( $>150$ plants) was significantly lower compared to control plants in low-density slick spots ( $\leq 150$ plants) (Fig. 3). The lower levels of seed loss experienced by control plants in high-density slick spots may be a result of predator satiation, which in harvester ants can result when the seed storage capacity of a nest is exhausted (Whitford and Ettershank 1975, Rissing 1989) or more generally when the food requirements of a colony are met (Gordon 1991). Alternatively, once a sufficient number of $L$. papilliferum seeds had been collected by foragers, colonies associated with high-density slick spots may have shifted their foraging efforts to other types of seeds to meet the colony's nutritional requirements (Kay 2004). Further study is needed to address these possibilities given that little is known about the seed capacity or nutritional requirements of $P$. salinus.

While low sample size may have contributed to the high variability in proportion of seeds lost to ants in slick spots with $>150$ plants, the comparative lack of variability in slick spots with fewer plants (apart from 2 cases) suggests that other factors may have been responsible.
For example, in high-density slick spots, once the total number of seeds available exceeded a colony's capacity or need to retrieve them, some plants may have largely escaped or experienced lower levels of seed predation than others. There is no reason to expect seed predation to be spread evenly across all plants in a slick spot when the patch contains more seeds than a colony can utilize. For example, both the timing of seeds reaching the soil surface and the distance ants must travel to reach specific plants may influence the timing and intensity of seed predation on individual plants. Although we did not account for the age or size of colonies in our study, differences in these parameters may also have influenced the satiation threshold of colonies (Gordon 1991) and contributed to variability in the proportion of seeds lost to ants.

Predator satiation is generally associated with massive, synchronous reproductive events by plants. In alpine ash, Eucalyptus delegatensis, the synchronous release of large numbers of stored seeds following fire results in satiation of granivorous ants and a greater number of emergent seedlings (O'Dowd and Gill 1984, see also Andersen 1987). Similarly, mast seeding, the intermittent and synchronous production of large seed crops by a population of perennial plants, is generally viewed as a strategy to reduce the impact of seed predation through predator satiation (Janzen 1971, Kelly 1994). In slickspot peppergrass, population sizes fluctuate widely in response to the amount and timing of precipitation during the previous winter (Kinter et al. 2013, Bond 2017). In favorable years, large seed crops within slick spots may result in predator satiation, thereby allowing many seeds to survive and enter the seed bank. By contrast, in unfavorable years when seed crops are low, seed predation may severely limit recruitment of seeds to the seed bank.

Many studies have shown that foraging decisions of harvester ants can change in response to the types of seeds available near nests (e.g., Crist and MacMahon 1992, Pirk et al. 2009, Miretti et al. 2019). While research to date suggests that $P$. salinus prefers $L$. papilliferum seeds to other seeds commonly available (Schmasow and Robertson 2016), it would be informative to compare the intensity of seed predation on L. papilliferum among populations and years to determine whether the 
results of our study are widely applicable. It is possible that the intensity of seed predation by harvester ants might differ among populations in response to the local plant community or other factors unique to sites.

Despite an abundance of research on the foraging ecology of Pogonomyrmex ants, there are few estimates of annual seed intake by colonies, and those that exist are best viewed as rough approximations given differences in the types of seeds collected by harvester ants and the need to extrapolate short-term measurements of foraging rates to seasonal intakes. Crist and MacMahon (1992) and Pirk and Lopez de Casenave (2006) estimated that colonies of $P$. occidentalis and $P$. rastratus collect $\sim 60,000$ and $\sim 81,000$ seeds, respectively, per season. Tschinkel (1999) found that colonies of $P$. badius stored up to 300,000 seeds within their nests, although it is unclear whether these stores were accumulated in a single season or over longer periods of time. While there are no estimates of seasonal seed intake by $P$. salinus colonies, it is reasonable to assume that the intake would be similar to other Pogonomyrmex species. Our finding that the proportion of seeds lost by plants declined when plant numbers in slick spots exceeded $150(\sim 200,000$ seeds-Schmasow 2015) provides a sense of how seed survivorship in L. papilliferum may be affected by Owyhee harvester ants. Overall, our results suggest that slick spots supporting large numbers of L. papilliferum in a given year may be buffered from the effects of seed predation by harvester ants, whereas those with relatively few plants may suffer high levels of seed loss. Lepidium papilliferum populations that consistently support only small numbers of plants, of which there are many (Miller and Kinter 2018), are likely to be particularly vulnerable to the detrimental effects of seed predation, given the longevity of ant colonies and the preference exhibited by these ants for L. papilliferum seeds.

\section{ACKNOWLEDgments}

Funding for this project was provided by the Idaho Army National Guard (IDARNG) and Boise State University. We thank Charles Baun (IDARNG) for his interest and support of the project; David Wisniewski, Triton Rimkus, Samantha Kirkendall, Tristan Froerer, and Krista Summers for assistance in the field and laboratory; Julie Heath and Laura Bond for assistance with statistical analyses; and Julie Heath and Marcelo Serpe for helpful comments on the manuscript.

\section{Literature Cited}

Albert, M.J., A. Escudero, And J.M. Iriondo. 2005. Assessing ant seed predation in threatened plants: a case study. Acta Oecologica 28:213-220.

ANCHETA, J., AND S.B. HEARD. 2011. Impacts of insect herbivores on rare plant populations. Biological Conservation 144:2395-2402.

Andersen, A.N. 1987. Effects of seed predation by ants on seedling densities at a woodland site in SE Australia. Oikos 48:171-174.

BonD, L. 2017. Trends in counts of slickspot peppergrass (Lepidium papilliferum) on habitat integrity and population monitoring transects, 2005-2015. Report prepared for United States Fish and Wildlife Service, Boise, ID.

Cole, A.C. 1968. Pogonomyrmex harvester ants: a study of the genus in North America. University of Tennessee Press, Knoxville, TN.

Crawley, M.J. 2000. Seed predator and plant population dynamics. Pages 167-182 in M. Fenner, editor, Seeds: the ecology of regeneration in plant communities. 2nd edition. CABI Publishing, Wallingford, United Kingdom.

Crist, T.O., AND J.A. MaCMAHON. 1991. Foraging patterns of Pogonomyrmex occidentalis (Hymenoptera: Formicidae) in a shrub-steppe ecosystem: the roles of temperature, trunk trails, and seed resources. Environmental Entomology 20:265-275.

Crist, T.O., and J.A. MacMahon. 1992. Harvester ant foraging and shrub-steppe seeds: interactions of seed resources and seed use. Ecology 73:1768-1779.

Fisher, H., L. Eslick, ANd M. SEYFried. 1996. Edaphic factors that characterize the distribution of Lepidium papilliferum. Idaho Bureau of Land Management Technical Bulletin No. 96-6, Boise ID.

Gordon, D.M. 1991. Behavioral flexibility and the foraging ecology of seed-eating ants. American Naturalist 138:379-411.

Hоввs, R.J. 1985. Harvester ant foraging and plant species distribution in annual grassland. Oecologia 67: $519-523$

Hölldobler, B., and E.O. Wilson. 1990. The ants. 1st edition. Harvard University Press, Cambridge.

Holmgren, N.H., P.K. Holmgren, and A. Cronquist. 2005. Intermountain flora, vascular plants of the Intermountain West, U.S.A. Volume 2, Part B, Subclass Dilleniidae. New York Botanical Garden Press, Bronx, NY.

Howell, B.D., And I.C. Robertson. 2015. Reclaiming lost territory: the response of Owyhee harvester ants to forager intrusions by neighboring colonies. Journal of Insect Behavior 28:722-731.

Inouye, R.S., G.S. Byers, AND J.H. Brown. 1980. Effects of predation and competition on survivorship, fecundity, and community structure of desert annuals. Ecology 61:1344-1351.

JanZEN, D.H. 1971. Seed predation by animals. Annual Review of Ecology and Systematics 2:465-492. 
JEFFRIES, M.I. 2016. An investigation of herbivory and seed predation on slickspot peppergrass. Master's thesis, Boise State University, Boise, ID. 94 pp.

Johnson, R.A. 2000. Seed-harvester ants (Hymenoptera: Formicidae) of North America: an overview of ecology and biogeography. Sociobiology 36:89-122.

Jorgensen, C.D., And S.D. PorTER. 1982. Foraging behavior of Pogonomyrmex owyheei in southeast Idaho. Environmental Entomology 11:381-384.

KAY, A. 2004. The relative availabilities of complementary resources affect the feeding preferences of ant colonies. Behavioral Ecology 15:63-70.

KELLY, D. 1994. The evolutionary ecology of mast seeding. Trends in Ecology and Evolution 9:465-470.

Kinter, C.L., J.R. Fulkerson, J.J. Miller, and D.L. CLAY. 2013. Draft habitat integrity and population monitoring of Lepidium papilliferum (slickspot peppergrass): 2012. Idaho Natural Heritage Program, Idaho Department of Fish and Game, Boise, ID.

MACKAY, W.P. 1981. A comparison of the nest phenologies of three species of Pogonomyrmex harvester ants (Hymenoptera: Formicidae). Psyche 88:25-74.

MacMahon, J.A., J.F. Mull, and T.O. Crist. 2000. Harvester ants (Pogonomyrmex spp.): their community and ecosystem influences. Annual Review of Ecology and Systematics 31:265-291.

Mancuso, M., AND R.K. Moseley. 1998. An ecological integrity index to assess and monitor Lepidium papilliferum (slickspot peppergrass) habitat in southwestern Idaho. Idaho Department of Fish and Game, Boise, ID.

Meyer, S.E., D. Quinney, And J. Weaver. 2005. A life history study of the Snake River plains endemic Lepidium papilliferum (Brassicaceae). Western North American Naturalist 65:11-23.

Miller, J.J., AND C.L. KinTER. 2018. Field assessment of Lepidium papilliferum (slickspot peppergrass) element occurrences: Snake River Plain and adjacent foothills. Report prepared for Idaho Natural Heritage Program, Idaho Department of Fish and Game, Boise, ID.

Miretti, M.F., J. Lopez de Casenave, and R.G. Pol. 2019. Stereotyped seed preferences of the harvester ant Pogonomyrmex mendozanus in the central Monte Desert. Arthropod-Plant Interactions 13:771-778.

Moseley, R.K. 1994. Report on the conservation status of Lepidium papilliferum. Idaho Department of Fish and Game, Boise, ID.

O’DowD, D.J., AND A.M. GILl. 1984. Predator satiation and site alteration following fire: mass reproduction of alpine ash (Eucalyptus delegatensis) in southeastern Australia. Ecology 65:1052-1066.

Pirk, G.I., And J. Lopez De Casenave. 2006. Diet and seed removal rates by the harvester ants Pogonomyrmex rastratus and Pogonomyrmex pronotalis in the central Monte Desert, Argentina. Insect Sociaux 53: 119-125.

Pirk, G.I., J. Lopez de Casenave, R.G. Pol, L. Marone, AND F.A. MILESI. 2009. Influence of temporal fluctuations in seed abundance on the diet of harvester ants (Pogonomyrmex spp.) in the central Monte Desert, Argentina. Austral Ecology 34:908-919.
PorTer, S.D., AND C.D. Jorgensen. 1988. Longevity of harvester ant colonies in southern Idaho. Journal of Range Management 41:104-107.

R Development Core Team. 2013. R: a language and environment for statistical computing. R Foundation for Statistical Computing, Vienna, Austria. http:// www.R-project.org

Reichman, O.J. 1979. Desert granivore foraging and its impact on seed densities and distributions. Ecology 60:1085-1092.

Rissing, S.W. 1989. Long-term regulation of the foraging response in a social insect colony (Hymenoptera: Formicidae: Pogonomyrmex). Journal of Insect Behavior 2:255-259.

Robertson, I.C., and W.G. Robertson. 2020. Colony dynamics and plant community associations of the harvester ant, Pogonomyrmex salinus (Hymenoptera: Formicidae) in sagebrush-steppe habitat. Environmental Entomology 49:983-992.

Robertson, I.C., and D. Klemash. 2003. Insect-mediated pollination in slickspot peppergrass, Lepidium papilliferum L. (Brassicaceae), and its implications for population viability. Western North American Naturalist 63:265-268.

Schmasow, M.S. 2015. Diet selection by the Owyhee harvester ant (Pogonomyrmex salinus) in southwestern Idaho. Master's thesis, Boise State University, Boise, ID.

Schmasow, M.S., and I.C. Robertson. 2016. Selective foraging by Pogonomyrmex salinus (Hymenoptera: Formicidae) in semiarid grassland: implications for a rare plant. Environmental Entomology 45:952-960.

Stephens, D.W., J.S. Brown, AND R.C. Ydenberg. 2007. Foraging behavior and ecology. University of Chicago Press, Chicago, IL.

TABER, S.W. 1998. The world of harvester ants. 1st edition. Texas A\&M University Press, College Station, TX.

TschinkeL, W.R. 1999. Sociometry and sociogenesis of colony-level attributes of the Florida harvester ants (Hymenoptera: Formicidae). Annals of the Entomological Society of America 92:80-89.

United States Fish and WiLdlife Service. 2016. Endangered and threatened wildlife and plants; threatened status for Lepidium papilliferum (slickspot peppergrass) throughout its range; Final Rule. Federal Register 81(159):55058-55084.

Wenninger, A., T.N. Kim, B.J. Spiesman, and C. GratTON. 2016. Contrasting foraging patterns: testing resource-concentration and dilution effects with pollinators and seed predators. Insects 7(2): Art. 23. 11 pp. https://doi.org/10.3390/insects7020023

White, J.P., AND I.C. RoberTson. 2009. Intense seed predation by harvester ants on a rare mustard. Ecoscience 16:508-513.

Whitford, W.G., and G. EtTershank. 1975. Factors affecting foraging activity in Chihuahuan desert harvester ants. Environmental Entomology 4:689-696.

Received 3 December 2019

Revised 16 April 2020 Accepted 8 May 2020

Published online 31 December 2020 
Copyright of Western North American Naturalist is the property of Monte L. Bean Life Science Museum and its content may not be copied or emailed to multiple sites or posted to a listserv without the copyright holder's express written permission. However, users may print, download, or email articles for individual use. 